\title{
Insight on the Enhanced Reversibility of a Multi-Metal Layered Oxide for Sodium-Ion Battery
}

\author{
Daniele Di Lecce ${ }^{\mathrm{a}}$, Daniele Campanella ${ }^{\mathrm{a}}$ and Jusef Hassoun ${ }^{\mathrm{a}, \mathrm{b}^{*}}$ \\ ${ }^{a}$ Department of Chemical and Pharmaceutical Sciences, University of Ferrara, Via Fossato di \\ Mortara, 17, 44121, Ferrara, Italy. \\ ${ }^{b}$ National Interuniversity Consortium of Materials Science and Technology (INSTM), University \\ of Ferrara Research Unit, University of Ferrara, Via Fossato di Mortara, 17, 44121, Ferrara, \\ Italy.
}

*Corresponding authors: jusef.hassoun@unife.it 


\begin{abstract}
Sodium-ion layered cathodes range along a vast variety of structures and chemical compositions which influence the physical-chemical characteristics and the electrochemical features in battery. In this work, we show that the synergistic effects of various metals, enhanced structure, and optimal morphology of a $\mathrm{Na}_{0.48} \mathrm{Al}_{0.03} \mathrm{Co} \mathrm{Co}_{18} \mathrm{Ni}_{0.18} \mathrm{Mn}_{0.47} \mathrm{O}_{2}$ material lead to a remarkable reversibility in sodium cell. XRD refinement evidences that the electrode has a P3/P2-type layered structure, while SEM study shows a morphology consisting of primary layers with nanometric thickness regularly stacked into uniform micrometric particles. In-depth investigation combining ex situ X-ray diffraction, galvanostatic intermittent titration, and voltammetry measurements reveals solid-solution $\mathrm{Na}^{+}$intercalation into the layered oxide between 1.4 and 4.6 $\mathrm{V}$ vs $\mathrm{Na}^{+} / \mathrm{Na}$ with relevant lattice stability. Furthermore, the study shows the absence of phase transitions during $\mathrm{Na}^{+}$exchange within the material framework, which advantageously leads to enhanced reversibility, benefiting from minor lattice change upon $\mathrm{Na}^{+}$intercalation, fast diffusion, improved electrode/electrolyte interphase and smooth voltage profile. Hence, the electrode delivers a maximum capacity of about $175 \mathrm{mAh} \mathrm{g}^{-1}$ with suitable cycling stability and Coulombic efficiency approaching $99 \%$ in sodium cell. Therefore, we believe that the study reported herein may shed light on important characteristics of this attracting class of electrodes, allowing efficient operation in next generation sodium-ion battery.
\end{abstract}




\section{Introduction}

Alkali metals, including lithium, sodium and potassium, have been studied since early eighties with the aim of developing batteries characterized by high energy, due to their very low redox potential (i.e., $-3.05 \mathrm{~V},-2.71 \mathrm{~V}$ and $-2.92 \mathrm{~V} v$ s SHE, respectively) and light weight (i.e., 6.94, 22.99 and $39.10 \mathrm{~g} \mathrm{~mol}^{-1}$, respectively). ${ }^{1}$ The extensive researches on rechargeable lithium cells based on the "rocking chair" concept ${ }^{2}$ well addressed the development of efficient and safe "lithium-ion" battery, thus favoring the latter rather than other alkali metals. Therefore, continuous R\&D has led to the commercialization of the lithium-ion battery by early nineties, and to further improvements during the last decades in terms of energy, power, and environmental sustainability, thereby triggering the global scale diffusion of a large variety of portable electronic devices. ${ }^{3}$ Recent increasing demand for Li-ion batteries due to the diffusion of emerging systems, such as renewable energy conversion plants and electric vehicles, affected the current balance between lithium consumption and production, ${ }^{4}$ thus newly focusing the efforts of the scientific community towards alternative alkali-metal batteries. ${ }^{5}$ Following this trend, Na-based batteries have been lately studied as possible electrochemical energy storage systems benefitting from the huge availability and low price of sodium, as well as the possibility of using aluminum instead of copper at the anode with additional advantage in terms of cost. ${ }^{6,7}$ Furthermore, the analogy between Na-ion and Li-ion insertion chemistry well facilitated the development of efficient sodium electrodes, in particular at the cathode side. ${ }^{8}$ Several $\mathrm{Na}^{+}$ exchanging materials have been investigated as high-performance positive electrodes, involving layered oxides, ${ }^{9-12}$ phosphates, ${ }^{13,14}$ pyrophosphates, ${ }^{15}$ NASICON-type materials, ${ }^{16,17}$ and cyanides. ${ }^{18-20}$ Among them, layered transition metal oxides $\left(\mathrm{Na}_{1-x} \mathrm{MeO}_{2}\right.$ where $\mathrm{Me}=\mathrm{Mn}, \mathrm{Fe}$, $\mathrm{Co}, \mathrm{Ni}, \mathrm{Ti}, \mathrm{V}, \mathrm{Cr}$ and $0<x<1$ ) have attracted great interest because of their $2 \mathrm{D}$ structure 
allowing relatively fast $\mathrm{Na}^{+}$intercalation and high capacity as well as due to a relatively easy synthetic procedure. ${ }^{9}$ These compounds have been classified according to two main structural classes, based on the either prismatic $(\mathrm{P})$ or octahedral $(\mathrm{O})$ environments of the sodium atoms between $\mathrm{MeO}_{6}$ edge-sharing octahedra. Thus, $\mathrm{O} 2, \mathrm{O} 3, \mathrm{P} 2$, and $\mathrm{P} 3$ structures are identified, taking into account the packing number of alkali ion layers within each unit cell, while O'3 and P'3 phases occur by a monoclinic distortion of the unit cell. Accordingly, the electrochemical (de)sodiation into $\mathrm{Na}_{1-x} \mathrm{MeO}_{2}$ materials in sodium cell generally involves reversible structural changes by varying the potential vs $\mathrm{Na}^{+} / \mathrm{Na}$, e.g., through O3/O'3/P3/P'3 and $\mathrm{P} 2 / \mathrm{O} 2(\mathrm{OP} 4)$ transformations, since different crystal arrangements are energetically favored when $\mathrm{Na}^{+}$ions are partly extracted. ${ }^{5,21-24}$ The aforementioned multiphase (de)intercalation pathways are typically reflected into a stepwise voltage profile ${ }^{25}$ and may hinder the $\mathrm{Na}^{+}$diffusion between the $\mathrm{MeO}_{6}$ planes. ${ }^{26}$ Therefore, layered materials characterized by the simultaneous presence of various metals in the structure have been investigated as suitable solution for stabilizing the $\mathrm{Na}_{1-x} \mathrm{MeO}_{2}$ lattice. ${ }^{27-29}$ In particular, sodium-intercalation oxides based on various transition metals, including the relatively low-cost, environmental friendly manganese, have attracted remarkable interest. ${ }^{26}$ Interestingly, the electronegativity of the involved metals, as well as stoichiometry and crystal phase of the layered oxide, strongly influences the electrochemical behavior of these materials in sodium cell. Indeed, metal incorporation into the $\mathrm{Na}_{1-x} \mathrm{MeO}_{2}$ framework can actually increase the average operating voltage and mitigate the adverse effects of multiple phase transitions on rate capability and electrode stability. ${ }^{26}$ Furthermore, proper tuning of the composition in terms of both transition metals ratio and sodium content may improve the thermal stability, ${ }^{10,30,31}$ that is, a typical issue of layered oxide cathodes ${ }^{5}$ which may be magnified by presence of conventional electrolyte solutions. ${ }^{32}$ Therefore, partial substitution of cobalt and 
nickel for manganese can suppress the low-voltage $\mathrm{Mn}^{3+}$ Jahn-Teller distortion, thereby improving the cyclability, ${ }^{33}$ and enhance the electrochemical process above $3 \mathrm{~V} v s \mathrm{Na}^{+} / \mathrm{Na},{ }^{34}$ while doping with electrochemically inactive metals, such as $\mathrm{Al}$ or $\mathrm{Mg}$, may widen the working voltage range by hindering possible detrimental phase transitions at low $\mathrm{Na}^{+}$content..$^{35,36}$

In this work we adopted this intriguing approach, and extended the concept of using different metals into a multi-metal layered oxide cathode containing manganese, cobalt, nickel and aluminum. The new material has a chemical formula $\mathrm{Na}_{0.48} \mathrm{Al}_{0.03} \mathrm{Co}_{0.18} \mathrm{Ni}_{0.18} \mathrm{Mn}_{0.47} \mathrm{O}_{2}$, detected by elemental analysis, and well defined morphology and structure revealed by electron microscopy and X-ray diffraction. A thorough investigation combining X-ray diffraction and impedance spectroscopy upon the electrochemical process of the material is carried out in order to reveal the crystal lattice evolution upon sodium (de)insertion between the metal oxide layers, and the consequent changes of the electrode/electrolyte interphase. Furthermore, the $\mathrm{Na}^{+}$ transport properties of the material are deeply investigated both by galvanostatic intermittent titration and by adopting the Randless-Sevcik trend during voltammetry. An intercalation degree of about 0.63 favors a maximum capacity as high as $175 \mathrm{mAh} \mathrm{g}^{-1}$, and stable electrochemical behavior of the material in sodium-cell. Therefore, the data suggest the $\mathrm{Na}_{0.48} \mathrm{Al}_{0.03} \mathrm{Co} 0.18 \mathrm{Ni}_{0.18} \mathrm{Mn}_{0.47} \mathrm{O}_{2}$ ( $\mathrm{NCAM}$ ) compound as suitable electrode reacting by fast and very reversible $\mathrm{Na}^{+}$intercalation into a mixed $\mathrm{P} 3 / \mathrm{P} 2$ framework without significant phase transitions. The synergistic effect of the various metals, with particular focus on Al doping, is indicated as the main reason accounting for the enhanced solid-solution reaction. This proposed composition actually improves the structure stability, thereby leading to a multi-metal oxide material that reversibly reacts by solid-solution mechanism within the wide potential range from 1.4 and $4.6 \mathrm{~V} v s \mathrm{Na}^{+} / \mathrm{Na}$. Thus, the reversibility of the intercalation process is enhanced 
compared to typical layered oxides exchanging $\mathrm{Na}^{+}$ions through several phase transitions, since may benefit from minor lattice change upon electrochemical reaction.

\section{Experimental}

$\mathrm{Na} 0.48 \mathrm{Al}_{0.03} \mathrm{Co} 0.18 \mathrm{Ni} 0.18 \mathrm{Mn} 0.47 \mathrm{O}_{2}$ (NCAM) was synthesized through a co-precipitation method, according to an optimized recipe reported in previous work. ${ }^{35}$ Aluminum nitrate nonahydrate $\left(\mathrm{Al}\left(\mathrm{NO}_{3}\right)_{4} \cdot 9 \mathrm{H}_{2} \mathrm{O}\right.$, Sigma-Aldrich, $\left.\geq 98 \%\right)$, cobalt(II)-nitrate hexahydrate $\left(\mathrm{Co}\left(\mathrm{NO}_{3}\right)_{2} \cdot 6 \mathrm{H}_{2} \mathrm{O}\right.$, Sigma-Aldrich, $\geq 99.0 \%)$ nickel(II) nitrate exahydrate $\left(\mathrm{Ni}\left(\mathrm{NO}_{3}\right)_{2} \cdot 6 \mathrm{H}_{2} \mathrm{O}\right.$, Sigma-Aldrich, $\geq$ 98.5\%), and manganese(II) nitrate tetrahydrate $\left(\mathrm{Mn}\left(\mathrm{NO}_{3}\right)_{2} \cdot 4 \mathrm{H}_{2} \mathrm{O}\right.$, Sigma-Aldrich, $\left.\geq 97.0 \%\right)$ were dissolved in deionized water to form a solution with a Al:Co:Ni:Mn molar ratio of 1:2:2:4.5. A $0.5 \mathrm{M} \mathrm{NaOH}$ aqueous solution was dropwise added to the nitrates solution in order to precipitate a hydroxide precursor (50 molar $\%$ excess with respect to the hydroxide). The hydroxide precursor was filtered, washed several times with deionized water, and dried overnight at $70{ }^{\circ} \mathrm{C}$ and for $12 \mathrm{~h}$ at $120{ }^{\circ} \mathrm{C}$ in a dry air flow. Afterwards, the precursor was mixed with sodium hydroxide $(\mathrm{NaOH}$ pellets, Sigma-Aldrich, $\geq 98 \%)$ in the 1:1 molar ratio. The resulting precursor was calcinated at $500{ }^{\circ} \mathrm{C}$ for $5 \mathrm{~h}$ in a dry air flow, and then grinded in a mortar, pelletized and calcinated at $1000^{\circ} \mathrm{C}$ for $6 \mathrm{~h}$ in a dry air flow.

Sample structure was investigated by X-ray diffraction (XRD) through a Bruker D8 Advance diffractometer equipped with a $\mathrm{CuK} \alpha$ source, by performing a scan in the $2 \theta$ range between $10^{\circ}$ and $80^{\circ}$ at a rate of $10 \mathrm{~s} \mathrm{step}^{-1}$ and using step size of $0.02^{\circ}$. The NCAM powder was placed on a glass sample holder for XRD. Rietveld refinement of the XRD pattern was performed through the MAUD software, ${ }^{37}$ according to the hexagonal $R 3 m$ (N. 160, ICSD 184736) and $P 6_{3} / m m c$ (N. 194, ICSD 291156) space groups. The refinement was carried out by fixing atom occupancies to the values estimated by energy dispersive X-ray spectroscopy (EDS, 
see below), except for the $P 6_{3} / m m c \mathrm{Na} 1$ and $\mathrm{Na} 2$ sites, whose occupancy was refined by fixing the overall $\mathrm{Na}$ content according to the EDS. Furthermore, the isotropic atomic displacement parameters have been constrained to the same value for $\mathrm{Al}, \mathrm{Mn}, \mathrm{Co}$, and $\mathrm{Ni}$ upon the refinement. The weighted-profile and the goodness-of-fit values were $\mathrm{R}_{\mathrm{wp}} \%=19.18$ and $\chi^{2}=3.18$, respectively. Sample morphology was studied by scanning electron microscopy (SEM) through a Zeiss EVO 40 microscope with a $\mathrm{LaB}_{6}$ thermoionic gun. Sample stoichiometry was estimated by EDS through the same instrument using X-ACT Cambridge Instrument analyzer.

Electrodes were prepared by doctor-blade coating on an aluminum current collector foil of a slurry formed by NCAM (80 wt.\%), PVDF binder (10 wt.\%, 6020, Solef Solvay), and Super P conductive agent (10 wt.\%, Timcal) in N-methyl pyrrolidone (NMP, Sigma-Aldrich). The coated aluminum foil was dried $3 \mathrm{~h}$ at $70{ }^{\circ} \mathrm{C}$ on a hot plate, cut into the form of 10 and $14 \mathrm{~mm}$ disks, and then dried overnight at $110{ }^{\circ} \mathrm{C}$ under vacuum. The active material loading of the electrode was $3.4 \pm 0.2 \mathrm{mg} \mathrm{cm}^{-2}$.

The electrolyte solution was prepared in an Ar-filled glovebox (MBraun, $\mathrm{O}_{2}$ and $\mathrm{H}_{2} \mathrm{O}$ content below $1 \mathrm{ppm}$ ) by dissolving $\mathrm{NaClO}_{4}$ in propylene carbonate (PC, water content lower than $10 \mathrm{ppm}$ as determined by using a 899 Karl Fischer Coulometer, Metrohm) at $1 \mathrm{M}$ concentration, and adding fluoroethylene carbonate (FEC) in a concentration of $20 \mathrm{wt} . \%$ with respect to the final solution. Sodium-metal electrode disks were prepared from sodium cubes (Sigma-Aldrich) by rolling and pressing. Two type of sodium cells where used for the various tests. CR2032 coin-cells (MTI) were assembled by using a sodium-metal disk, a Whatman® GF/D glass fiber separator soaked by the electrolyte solution, and an NCAM electrode disk with diameter of $14 \mathrm{~mm}$. T-type cells were assembled by using sodium-metal disks as the counter and 
reference electrodes, respectively, a Whatman ${ }^{\circledR}$ GF/D glass fiber separator soaked by the electrolyte solution, and an NCAM electrode disk with diameter of $10 \mathrm{~mm}$.

Cyclic voltammetry (CV) measurements were carried out on T-cells with a threeelectrode configuration by using a VersaSTAT MC Princeton Applied Research (PAR) potentiostat. The CV experiments were performed at scan rates of $0.05,0.1,0.15$, and $0.2 \mathrm{mV} \mathrm{s}^{-1}$ between 1.4 and $4.6 \mathrm{~V}$ vs $\mathrm{Na}^{+} / \mathrm{Na}$, and used to calculate the sodium diffusion coefficient $\left(D_{\mathrm{CV}}\right)$. The CV profiles reported in this work at each scan rate correspond to steady-state cycles, performed upon stabilization cycles (data not reported). Galvanostatic intermittent titration technique (GITT) was applied on a three-electrode T-cell, after $24 \mathrm{~h}$ of rest at the OCV and three galvanostatic cycles at $60 \mathrm{~mA} \mathrm{~g}^{-1}$ between 1.5 and $4.5 \mathrm{~V}$ vs $\mathrm{Na}^{+} / \mathrm{Na}$ performed to reach the steady-state condition of the cell. GITT was carried out by applying square current pulses of 60 $\mathrm{mA} \mathrm{g}^{-1}$ for $1360 \mathrm{~s}$, followed by relaxation steps of $1 \mathrm{~h}$ at the OCV.

Ex situ XRD measurements at several states of charge were performed using T-type cells with two-electrode configuration. Fifteen cells were prepared and galvanostatically cycled, after $24 \mathrm{~h}$ of rest, at $60 \mathrm{~mA} \mathrm{~g}^{-1}$ within the voltage ranging from $1.4 \mathrm{~V}$ to $4.6 \mathrm{~V}$, to reach different states of charge. Each cell was then disassembled in an Ar-filled glovebox (MBraun, $\mathrm{O}_{2}$ and $\mathrm{H}_{2} \mathrm{O}$ content below $1 \mathrm{ppm})$. The electrodes were recovered from the cells, washed several times with dimethyl carbonate (DMC), dried few minutes under vacuum, and sealed on a glass sample holder for XRD by using adhesive tape. XRD patterns were recorded for the following cell conditions: at the open circuit voltage (OCV) of about $3 \mathrm{~V}$; after charge to 3.8 and $4.6 \mathrm{~V}$; after charge to $4.6 \mathrm{~V}$ and subsequent discharge to $3.8,3,2.3$ and $1.4 \mathrm{~V}$; after 1 charge/discharge cycle and subsequent charge to $2.5,3,3.8$ and $4.6 \mathrm{~V}$; after 1 charge/discharge cycle, charge to $4.6 \mathrm{~V}$, and subsequent discharge to 3.8, 3, 2.3 and $1.4 \mathrm{~V}$. The ex situ XRD measurements were 
performed through a Bruker D8 Advance diffractometer equipped with a $\mathrm{CuK} \alpha$ source, from $10^{\circ}$ to $90^{\circ}(2 \theta)$ with step size of $0.02^{\circ}$ and scan rate of $2 \mathrm{~s} \mathrm{step}^{-1}$.

Before disassembling for the above described ex situ XRD tests, electrochemical impedance spectroscopy (EIS) measurements were carried out on the cells by applying a $10 \mathrm{mV}$ amplitude signal within the $500 \mathrm{kHz}-50 \mathrm{~Hz}$ range through a VersaSTAT MC Princeton Applied Research (PAR) potentiostat. The impedance spectra were analyzed by nonlinear least squares (NLLS) method using the Boukamp package. ${ }^{38,39}$

CR2032 coin-cells (MTI) were cycled at constant current values of 15, 60, and $120 \mathrm{~mA}$ $\mathrm{g}^{-1}$ in the voltage range between 1.4 and $4.6 \mathrm{~V}$, after $24 \mathrm{~h}$ of rest at the OCV. A rate capability test was performed on a CR2032 coin-cell (MTI) after $24 \mathrm{~h}$ of rest at the OCV, by using current rates of $15,30,60,120$, and $240 \mathrm{~mA} \mathrm{~g}^{-1}$, increasing after 5 cycles, and then decreasing back the current to $15 \mathrm{~mA} \mathrm{~g}^{-1}$ in the voltage range between 1.4 and $4.6 \mathrm{~V}$. All the galvanostatic measurements were carried out through a MACCOR Series 4000 battery test system.

All the measurements were performed at room temperature $\left(25^{\circ} \mathrm{C}\right)$.

\section{Results and discussion}

Structure and atomic composition of the NCAM material have been studied by coupling XRD and EDS, which allowed data refinement, schematic representation of the crystalline phases, and determination of volume ratio and cell parameters of the layered oxide (Fig. 1). Indeed, the XRD pattern of Fig. S1 (Supporting Information) reveals reflections indexed to the hexagonal P3 and P2 structures, while the EDS analysis of Fig. S2 (Supporting Information) indicates the Na0.48 $\pm 0.16 \mathrm{Al}_{0.03 \pm 0.01} \mathrm{Co} 0.18 \pm 0.04 \mathrm{Ni} 0.18 \pm 0.04 \mathrm{Mn} 0.47 \pm 0.12 \mathrm{O}_{2.00 \pm 0.03}$ stoichiometry, thus suggesting successful incorporation of the transition metals in the layered lattice. Furthermore, the EDS reveals stoichiometric coefficients close to the values expected by the molar ratio of the 
precursors, except for $\mathrm{Al}$ which has lower amount possibly due to partial aluminum hydroxide precipitation upon synthesis (see Experimental section for details). Therefore, the XRD pattern of Fig. 1 has been refined by constraining the atoms occupancy according to the EDS results, and considering both the $\mathrm{P} 3$ and the $\mathrm{P} 2$ phases having the $R 3 m$ (number 160) and $P 6_{3} / m m c$ (number 194) space groups, respectively. The data refinement suggests the coexistence of the two phases with volume ratio of $79 \%$ for $\mathrm{P} 3$ and $21 \%$ for $\mathrm{P} 2$, and allows schematic representation of the structures (Fig. 1 inset) as well as determination of the unit cell parameters (a, c in Fig. 1 inset) associated with parallel and perpendicular axes to $\mathrm{MeO}_{6}$ octahedra layers, respectively. Interestingly, the NCAM material investigated herein shows a predominant P3 phase, while previous works on Mn-based layered cathodes prepared by a similar method using high calcination temperature and stoichiometric sodium content evidenced the preferential formation of the P2 phase rather than $\mathrm{P} 3,{ }^{5}$ which is instead favored by low temperature and understoichiometric sodium amount. ${ }^{34}$ Therefore, we may reasonably assume that the relative ratio of the various metals in $\mathrm{Na}_{x} \mathrm{Al}_{y} \mathrm{MeO}_{2}$ materials remarkably affects crystal structure and phase composition, besides the synthesis conditions. 


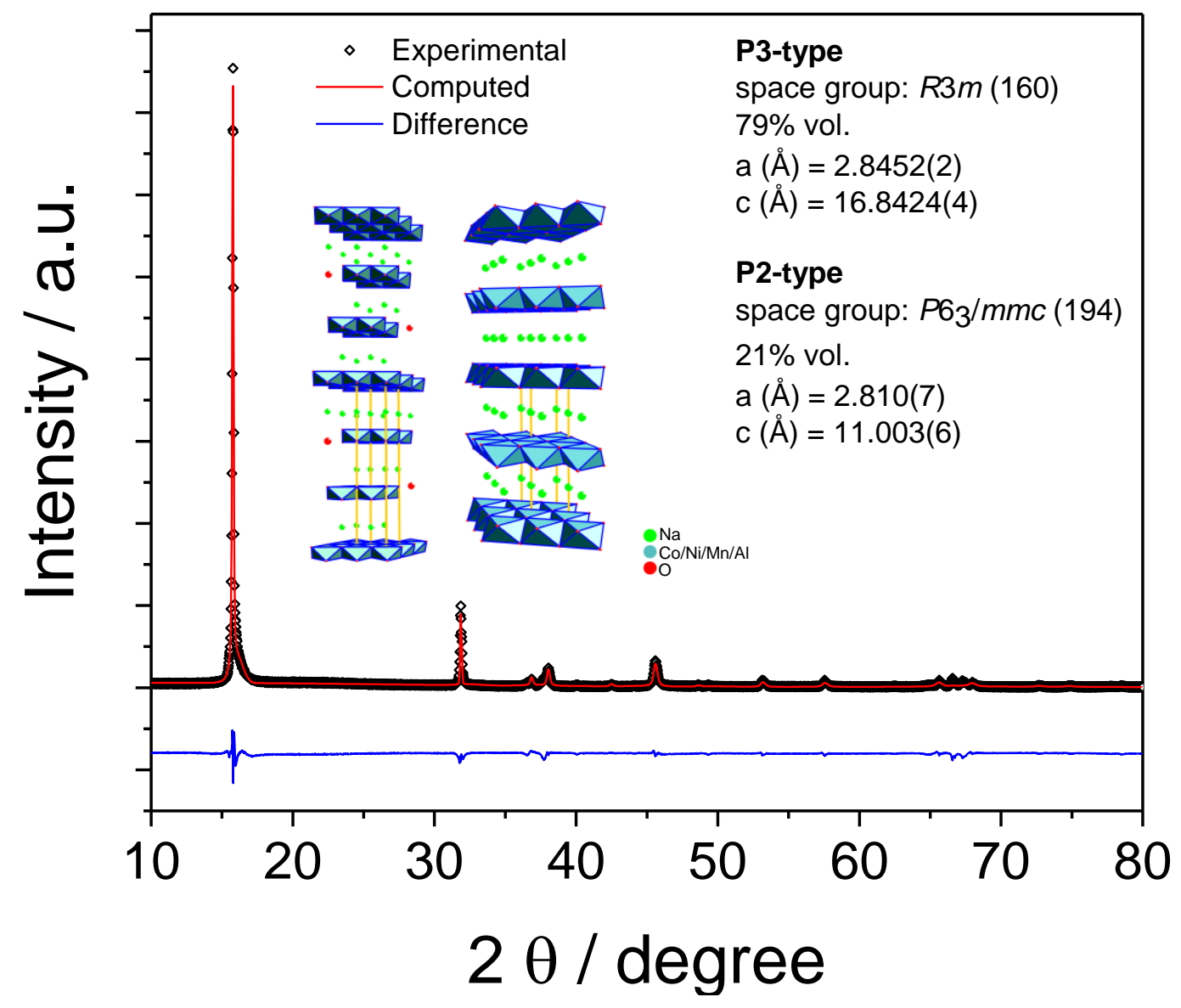

Figure 1. Rietveld refinement of the $\mathrm{Na}_{0.48} \mathrm{Al}_{0.03} \mathrm{Co} 0.18 \mathrm{Ni}_{0.18} \mathrm{Mn}_{0.47} \mathrm{O}_{2}$ powder. In detail: experimental (black dots) and computed (red line) patterns; difference plot (blue line); schematic representation of the refined P3 and P2 crystalline phases in the $\mathrm{Na}_{0.48} \mathrm{Al}_{0.03} \mathrm{Co}{ }_{18} \mathrm{Ni}_{0.18} \mathrm{Mn}_{0.47} \mathrm{O}_{2}$ powder with related indication of volume ratio and structure parameters (see Fig. S1 in the Supporting Information reporting the indexed XRD pattern with reference bars of the P3 and P2 phases).

Advantageously, multi-metal substitution in the $\mathrm{Na} 0.48 \mathrm{Al} 0.03 \mathrm{Co} 0.18 \mathrm{Ni} 0.18 \mathrm{Mn} 0.47 \mathrm{O}_{2}$ material may reflect into an electrochemical process with limited phase transitions upon sodium (de)insertion in view of a mitigated $\mathrm{Mn}^{3+} \mathrm{Jahn}$-Teller distortion. ${ }^{26}$ On the other hand, as already mentioned, incorporation several active (e.g., $\mathrm{Co}, \mathrm{Ni}, \mathrm{Fe})$ or inactive (e.g., $\mathrm{Al}, \mathrm{Ti})$ transition metals into $\mathrm{Mn}$ - 
based oxide cathodes for sodium batteries has proven to stabilize the layered structure during $\mathrm{Na}^{+}$reversible intercalation within a wide potential range. ${ }^{27,33,35,36,40}$

Defined layered morphology, a controlled particle size, and a uniform distribution are crucial parameters for determining the electrode/electrolyte interphase characteristics as well as the material behavior in terms of efficiency and cycle life in sodium cell. ${ }^{41}$ Indeed, irregular layers stacking and excessive aggregation can actually hinder the ion diffusion into the material framework, and severely limit the metal oxide conductivity, ${ }^{42}$ while too small and dispersed particles, e.g. at the nanometer level, may increase the electrode surface area and catalyze side reactions such as oxidative electrolyte decomposition at high voltage values. ${ }^{43}$ Fig. 2 shows the SEM images of the NCAM at increasing magnification, and reveals for the sample a very homogenous distribution of micrometric flakes with size ranging from $5 \mu \mathrm{m}$ to $30 \mu \mathrm{m}$ (Fig. 2a). Remarkably, these secondary flakes are uniformly constituted by stacked primary layers (Fig. 2b) with a nanometric thickness and a notable ordering level (Fig. 2c), thus in full agreement with the XRD refined structures of the layered metal oxide reported in insets of Fig. 1. It is worth mentioning that such a particularly ordered morphology, obtained for layered $\mathrm{Na}_{x} \mathrm{MeO}_{2}$ materials by adopting an optimized synthetic pathway, can ensure a low interphase resistance due to fast $\mathrm{Na}^{+}$(de)intercalation within the 2D layers, thus allowing limited cell polarization during the evolution of the electrochemical process. ${ }^{35}$ Furthermore, the uniform micrometric size observed by SEM generally limits the electrolyte decomposition, thus increasing the Coulombic efficiency and the stability of the material in sodium cell, while ensures at the same time relatively high tap density and electrode loading, as well as relevant practical capacity. ${ }^{44,45}$ 


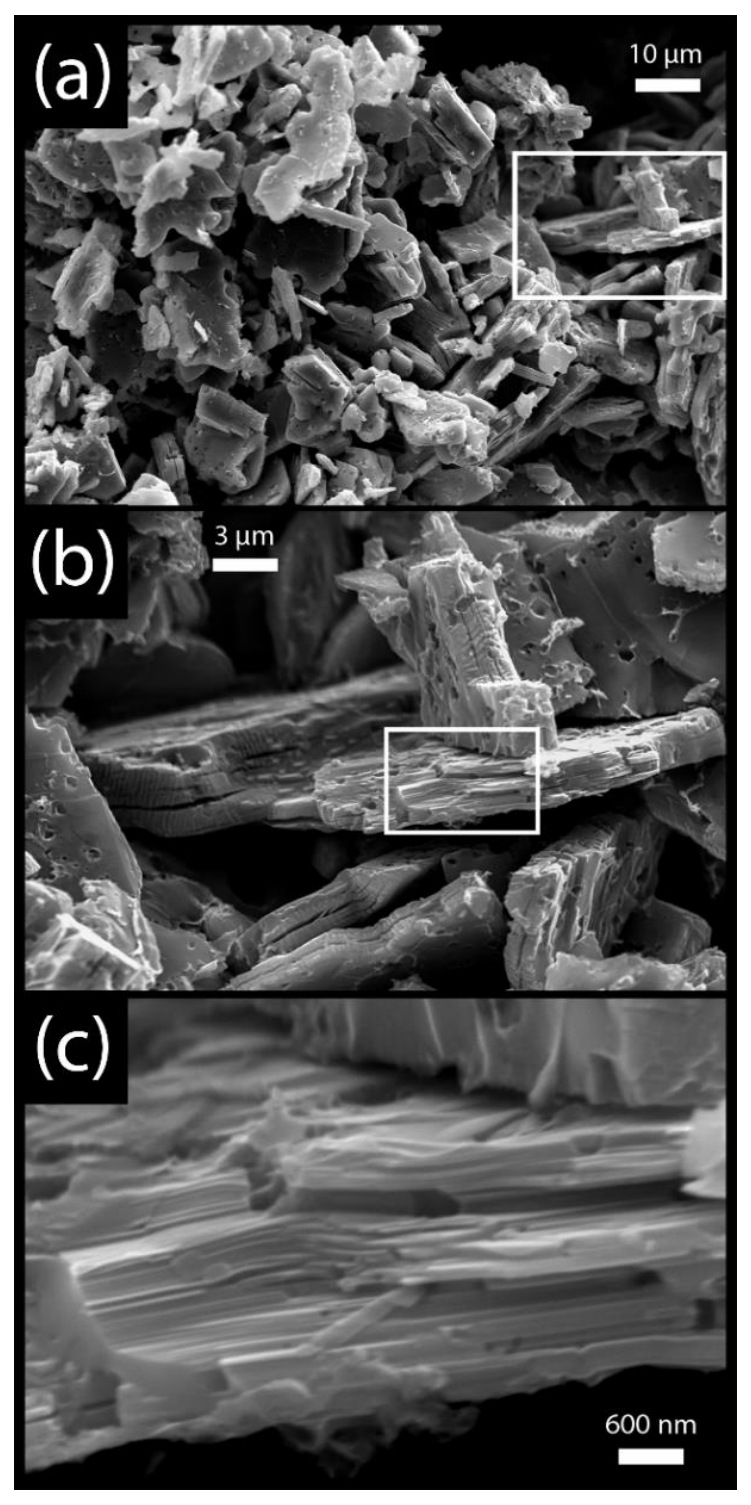

Figure 2. SEM images at various magnifications of the $\mathrm{Na}_{0.48} \mathrm{Al}_{0.03} \mathrm{Co}_{0.18} \mathrm{Ni}_{0.18} \mathrm{Mn}_{0.47} \mathrm{O}_{2}$ powder.

The electrochemical process of the NCAM electrode as well as the $\mathrm{Na}^{+}$diffusion characteristics into the layered framework are investigated by CV and GITT as reported in Fig. 3. The voltammetry curves, performed at increasing scan rates (Fig. 3a, top panel), reveal reversible electrochemical $\mathrm{Na}^{+}$(de)intercalation process characterized by several peaks, mostly occurring within $1.5-4.5 \mathrm{~V} v s \mathrm{Na}^{+} / \mathrm{Na}$. Although attribution of each peak to a specific electrochemical phenomenon may be not unambiguous, we may reasonably associate the signals 
at low voltage to the reversible $\mathrm{Mn}^{4+} / \mathrm{Mn}^{3+}$ redox process and attribute the high voltage activity to the $\mathrm{Ni}^{4+} / \mathrm{Ni}^{2+}$ and $\mathrm{Co}^{4+} / \mathrm{Co}^{3+}$ couples. ${ }^{34,35}$ Accordingly, the steady-state $\mathrm{CV}$ curves reveal three groups of oxidation peaks within the ranges $2.2-3.3 \mathrm{~V}, 3.4-4.0 \mathrm{~V}$ and $4.2-4.5 \mathrm{~V} v s \mathrm{Na}^{+} / \mathrm{Na}$, reversed during reduction within $4.3-3.9 \mathrm{~V}, 3.8-2.1 \mathrm{~V}$, and $2.0-1.5 \mathrm{~V} v s \mathrm{Na}^{+} / \mathrm{Na}$. The voltammograms also evidence more defined and less polarized peaks at the lower scan rate $(0.05$ $\left.\mathrm{mV} \mathrm{s}^{-1}\right)$ compared to the broader and merged peaks at the higher scan rate $\left(0.2 \mathrm{mV} \mathrm{s}^{-1}\right)$, due to the expected kinetic limits associated with the relatively slow ions motion within the solid-state electrode layers. ${ }^{46}$ Furthermore, the curves reveal increasing peak currents by rising the scan rate due to the nature of the $\mathrm{CV}$ test, which allows the determination of the $\mathrm{Na}^{+}$diffusion coefficient at various potentials both during oxidation and reduction by applying the Randles-Sevcik equation (1): ${ }^{47}$

$$
I_{P}=0.4463 z F A C \sqrt{\frac{z F v D_{C V}}{R T}}
$$

where $I_{P}(\mathrm{~A})$ is the current peak value, $z$ (considered 1) is the number of exchanged electrons, $F$ $\left(96485 \mathrm{C} \mathrm{mol}^{-1}\right)$ is the Faraday constant, $A\left(\mathrm{~cm}^{2}\right)$ is the electrode geometric area, $\mathrm{C}\left(\mathrm{mol} \mathrm{cm}^{-3}\right)$ is the $\mathrm{Na}^{+}$concentration within the layered lattice calculated considering the molar volume determined from the unit cell volume according to the Rietveld refinement of the XRD pattern $\left(V_{m}=23.49 \mathrm{~cm}^{3} \mathrm{~mol}^{-1}\right)$ and the nominal sodium content estimated by EDS $(0.48) ; v\left(\mathrm{~V} \mathrm{~s}^{-1}\right)$ is the scan rate, $R\left(\mathrm{~J} \mathrm{~K}^{-1} \mathrm{~mol}^{-1}\right)$ is the gas constant, and $T(298 \mathrm{~K})$ is the temperature. In particular, the voltammetry peaks marked in Fig. 3a linearly increase with the square root of the scan rate, as shown in Fig. S3 of the Supporting Information. Therefore, the slope of the $I_{P} v s v^{1 / 2}$ plot of these peaks has been used to calculate the apparent $\mathrm{Na}^{+}$diffusion coefficient, $D_{\mathrm{CV}}\left(\mathrm{cm}^{2} \mathrm{~s}^{-1}\right)$. The $\mathrm{CV}$ shows a $D_{\mathrm{CV}}$ decreasing as the potential increases (Fig. 3a, bottom panel), thereby suggesting 
slower $\mathrm{Na}^{+}$motion within charged $\mathrm{Na}_{1-x} \mathrm{Al}_{0.03} \mathrm{Co} 0 .{ }_{18} \mathrm{Ni}_{0.18} \mathrm{Mn}_{0.47} \mathrm{O}_{2}$ material. In particular, the sodium diffusion coefficient estimated by CV ranges within the $10^{-12}$ and $10^{-11} \mathrm{~cm}^{2} \mathrm{~s}^{-1}$ range. The $\mathrm{Na}^{+}$intercalation into $\mathrm{Na}_{1-x} \mathrm{Al}_{0.03} \mathrm{Co} 0.18 \mathrm{Ni0} .18 \mathrm{Mn} 0.47 \mathrm{O}_{2}$ has been further studied by GITT within potential ranging from 1.5 to $4.5 \mathrm{~V} v s \mathrm{Na}^{+} / \mathrm{Na}$ (Fig. 3b). Prior to the measurement, the cell has been galvanostatically charged and discharged at $60 \mathrm{~mA} \mathrm{~g}^{-1}$ for three cycles. Fig. S4 in the Supporting Information shows the related potential profiles as a function of the $\mathrm{Na}^{+}$exchange degree, i.e., $x$ in $\mathrm{Na}_{1-x} \mathrm{Al}_{0.03} \mathrm{Co}_{0.18} \mathrm{Ni}_{0.18} \mathrm{Mn}_{0.47} \mathrm{O}_{2}$. This preliminary galvanostatic test has a key role for determining experimental conditions for GITT such as the overall time used for charging and discharging the electrode as well as number and duration of the potential pulses.

Fig. S4 shows initial charge involving the removal of about $0.3 \mathrm{Na}^{+}$equivalents due to the partially desodiated state of the pristine electrode at the OCV. Subsequently, the electrode material reversibly exchanges about $0.63 \mathrm{Na}^{+}$equivalents during discharge and charge processes through a potential curve with a rather constant slope suggesting a solid-solution mechanism. ${ }^{33}$ Hence, the NCAM material exhibits a reversible electrochemical process evolving within the composition range from $\mathrm{Na}_{0.80} \mathrm{Al}_{0.03} \mathrm{Co} 0.18 \mathrm{Ni}_{0.18} \mathrm{Mn}_{0.47} \mathrm{O}_{2}$ at $1.5 \quad \mathrm{~V} \quad v s \quad \mathrm{Na}^{+} / \mathrm{Na}$ to $\mathrm{Na} 0.17 \mathrm{Al}_{0.03} \mathrm{Co}_{0.18} \mathrm{Ni}_{0.18} \mathrm{Mn}_{0.47} \mathrm{O}_{2}$ at $4.5 \mathrm{~V} v s \mathrm{Na}^{+} / \mathrm{Na}$, with a profile reflecting the redox reactions described by CV (Fig 3a, top panel). Top panel of Fig. 3b reports the quasi-equilibrium potential curve upon charge and discharge, in which the electrode potential upon cell relaxation $\left(E_{0}\right)$ is plotted as a function of the sodium exchange degree $(x)$, while Fig. S5a in the Supporting Information reveals a detail of the charge titration curve. Interestingly, top panel of Fig. $3 \mathrm{~b}$ shows a linear variation of $E_{0}$ by changing $x$ between the $\mathrm{Na}_{0.70} \mathrm{Al}_{0.03} \mathrm{Co}_{0.18} \mathrm{Ni}_{0.18} \mathrm{Mn}_{0.47} \mathrm{O}_{2}$ and $\mathrm{Na} 0.26 \mathrm{Al}_{0.03} \mathrm{Co}_{0.18} \mathrm{Ni}_{0.18} \mathrm{Mn}_{0.47} \mathrm{O}_{2}$ compositions, thus confirming the above supposed solid-solution mechanism. As already mentioned, GITT allows the determination of the apparent $\mathrm{Na}^{+}$diffusion 
coefficient, $D_{\text {GITT }}\left(\mathrm{cm}^{2} \mathrm{~s}^{-1}\right)$, through the analysis of the titration curve according to the method proposed by Weppner et al. ${ }^{47-49}$ Thus, each current pulse (Fig. S5a of the Supporting Information) has been analyzed by linear fit of $E v s$ time $^{1 / 2}$ for intervals $\ll \tau$ (where $\tau$ is the diffusion time) as shown in Fig. S5b of the Supporting Information, and a differential plot of $d E_{0} / d x$ vs $x$ in $\mathrm{Na}_{1-x} \mathrm{Al}_{0.03} \mathrm{Co}_{0.18} \mathrm{Ni}_{0.18} \mathrm{Mn}_{0.47} \mathrm{O}_{2}$ has been built (Fig. S5c of the Supporting Information). Therefore, $D_{\text {GITT }}$ for each pulse has been calculated by using the equation (2): ${ }^{47-49}$

$$
D_{G I T T}=\frac{4}{\pi}\left(\frac{V_{m} I}{A F}\right)^{2} \frac{\left(\frac{d E_{0}}{d x}\right)^{2}}{\left(\frac{d E}{d \sqrt{t}}\right)^{2}} \quad, \quad t \ll \tau
$$

where $V_{m}\left(23.49 \mathrm{~cm}^{3} \mathrm{~mol}^{-1}\right)$ is the molar volume calculated from the unit cell volume determined by Rietveld refinement of the XRD pattern, $I(\mathrm{~A})$ is the applied current, $A\left(\mathrm{~cm}^{2}\right)$ is the electrode geometric area, and $F\left(96485 \mathrm{C} \mathrm{mol}^{-1}\right)$ is the Faraday constant. Bottom panel of Fig. 3b reports the $D_{\text {GITT }}$ trend as a function of the $\mathrm{Na}^{+}$exchange degree $(x)$. GITT reveals apparent sodium coefficient ranging from $10^{-13}$ to $10^{-9} \mathrm{~cm}^{2} \mathrm{~s}^{-1}$, with values and trend in full agreement with the CV measurements. In particular, the $\mathrm{Na}^{+}$diffusion in $\mathrm{Na}_{1-x} \mathrm{Al}_{0.03} \mathrm{Co} 0.18 \mathrm{Ni}_{0.18} \mathrm{Mn}_{0.47} \mathrm{O}_{2}$ is fast for $0.35<x<0.72$, with $D_{\text {GITT }}$ of about $10^{-9} \mathrm{~cm}^{2} \mathrm{~s}^{-1}$, and gradually slows for $x>0.72$, with minimum value of about $10^{-10} \mathrm{~cm}^{2} \mathrm{~s}^{-1}$ at $x \approx 0.8$. Furthermore, the $\mathrm{Na}^{+}$motion is hindered into the almost fully $\mathrm{Na}_{1-x} \mathrm{Al}_{0.03} \mathrm{Co}_{0.18} \mathrm{Ni}_{0.18} \mathrm{Mn}_{0.47} \mathrm{O}_{2}$ lattice, as revealed by apparent diffusion coefficient values decreasing down to $10^{-13} \mathrm{~cm}^{2} \mathrm{~s}^{-1}$ for $x<0.35$. 

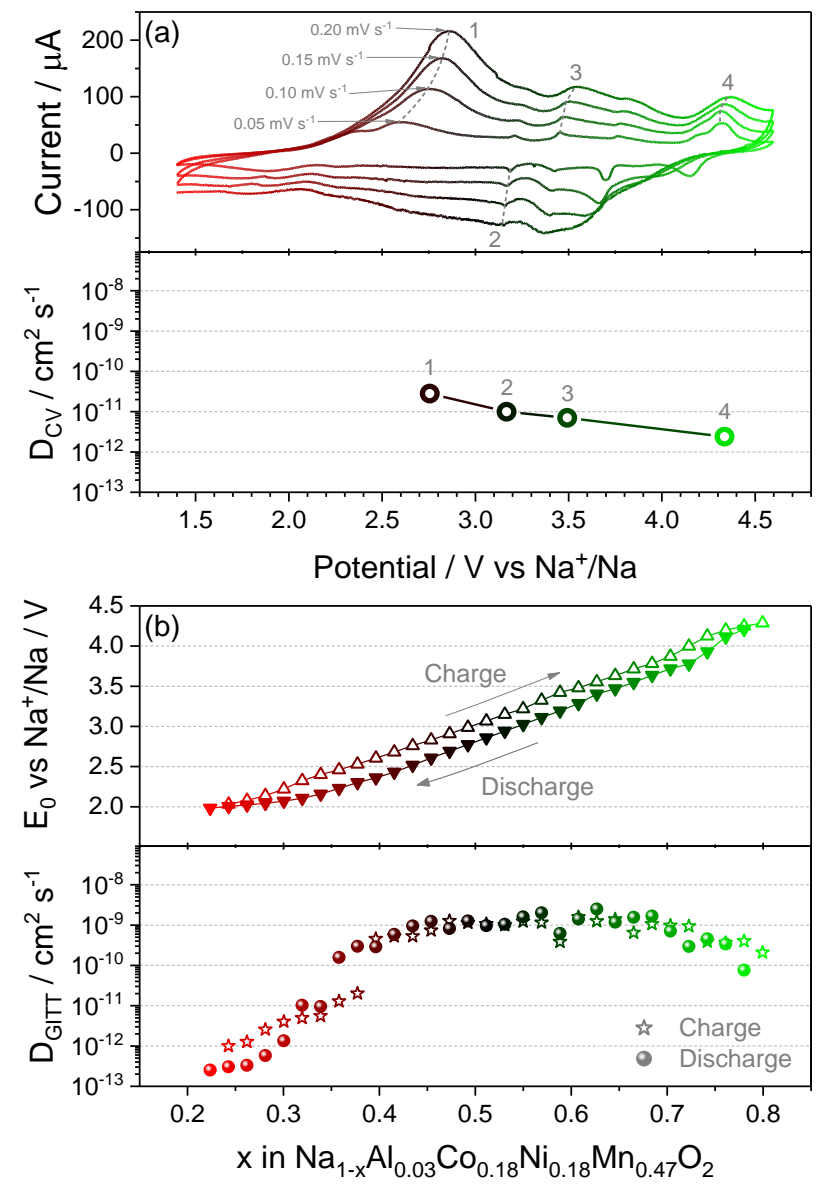

Figure 3. $\mathrm{Na}^{+}$diffusion coefficient $(D)$ determination by $\mathrm{CV}\left(D_{\mathrm{CV}}\right)$ and by GITT $\left(D_{\mathrm{GITT}}\right)$ for the $\mathrm{Na} 0.48 \mathrm{Al}_{0.03} \mathrm{Co}_{0.18} \mathrm{Ni}_{0.18} \mathrm{Mn}_{0.47} \mathrm{O}_{2}$ cathode in three-electrode T-cell using $1 \mathrm{M} \mathrm{NaClO} 4 \mathrm{PC}, 20$ wt\% FEC as electrolyte, and sodium metal as counter and reference electrodes. (a) Top panel: steadystate $\mathrm{CV}$ profiles of the $\mathrm{Na} 0.48 \mathrm{Al}_{0.03} \mathrm{Co} 0.18 \mathrm{Ni} 0.18 \mathrm{Mn}_{0.47} \mathrm{O}_{2}$ electrode at scan rates $(v)$ of $0.05,0.1$, 0.15 , and $0.2 \mathrm{mV} \mathrm{s}^{-1}$ between 1.4 and $4.6 \mathrm{~V} v s \mathrm{Na}^{+} / \mathrm{Na}$, with indication of the current peaks $\left(I_{p}\right)$ used for the $D_{\mathrm{CV}}$ determination; bottom panel: $D_{\mathrm{CV}}$ calculated from the $I_{p}$ values of the CV by applying the Randles-Sevcik equation (1) (see the related $I_{p} v s v^{1 / 2}$ plots of Fig. S3 in the Supporting Information). (b) Top panel: quasi-equilibrium potential after OCV relaxation $\left(E_{0}\right)$ determined by GITT as a function of $\mathrm{Na}^{+}$exchange degree $\left(x\right.$ in $\mathrm{Na}_{1-x} \mathrm{Al}_{0.03} \mathrm{Co} 0.18 \mathrm{Ni} 0.18 \mathrm{Mn}_{0.47} \mathrm{O}_{2}$, see the related GITT profile in Fig. S5 in the Supporting Information and the Experimental section for further details about the adopted procedure); bottom panel: $D_{\text {GITT }}$ as determined by GITT $^{48}$ as a function of $\mathrm{Na}^{+}$exchange degree $\left(x\right.$ in $\mathrm{Na}_{1-x} \mathrm{Al}_{0.03} \mathrm{Co}_{0.18} \mathrm{Ni}_{0.18} \mathrm{Mn}_{0.47} \mathrm{O}_{2}$, see the Supporting Information and the Experimental section for further details about the adopted procedure). 
The reversibility of the $\mathrm{Na}^{+}$insertion process has been investigated by ex situ XRD of NCAM electrodes collected from sodium cells at several states of charge (Fig. 4a-d). Fig. 4a reports the voltage profile of the Na/NCAM cell upon two galvanostatic cycles at $60 \mathrm{~mA} \mathrm{~g}^{-1}$, with indication by colored circles along the profile of the states of charge corresponding to $e x$ situ XRD investigation (see the Experimental section for further details about sample preparation). The figure reveals the voltage profile already described during discussion of $\mathrm{CV}$ and GITT (Fig. 3), characterized by a short initial charge due to the defective sodium content in the pristine material, and merged discharge/charge plateaus with sloped trend typical of the solidsolution (de)intercalation mechanism. Panels b-d of Fig. 4 report the related XRD patterns in the $2 \theta$ ranges that respectively show the $\left(\begin{array}{lll}0 & 0 & 3\end{array}\right),\left(\begin{array}{lll}0 & 0 & 6\end{array}\right),\left(\begin{array}{lll}0 & 0 & 12\end{array}\right)$ reflections of the $\mathrm{P} 3$ phase and the (lo 0 2 2), (l $\left.\begin{array}{lll}0 & 4\end{array}\right)$ reflections of the P2 phase. Remarkably, Ex situ XRD evidences the absence of noticeable structural changes upon the electrochemical reaction, besides the reversible intercalation of sodium ions within both the P3 and the P2 phases. Indeed, the shift of the P3 ( 00 3), ( ( $\left.\begin{array}{lll}0 & 0 & 6\end{array}\right),\left(\begin{array}{lll}0 & 0 & 12\end{array}\right)$ reflections and the P2 (l $\left.\begin{array}{lll}0 & 0 & 2\end{array}\right),\left(\begin{array}{lll}0 & 0 & 4\end{array}\right)$ reflections towards lower $2 \theta$ upon charge indicates increase of the c parameter for both unit cells, owing to the interlayer expansion promoted by repulsion of the negative charges of the oxygens between different $\mathrm{MeO}_{6}$ layers due to $\mathrm{Na}^{+}$ions deintercalation. The opposite shift with notable symmetry is observed upon discharge, thereby reflecting the $\mathrm{MeO}_{6}$ interlayer contraction as the negative charges are screened by the intercalated $\mathrm{Na}^{+} \cdot 33,40,50,51$ Such an enhanced reversibility is retained upon the two galvanostatic cycles, thus suggesting only limited effects on the $\mathrm{P} 3 / \mathrm{P} 2$ structure of $\mathrm{Na}^{+}$ concentration change within the $\mathrm{Na}_{1-x} \mathrm{Al}_{0.03} \mathrm{Co}_{0.18} \mathrm{Ni}_{0.18} \mathrm{Mn}_{0.47} \mathrm{O}_{2}$ structure. The Nyquist plots of the EIS measurements performed on the same Na/NCAM cells shown in Fig. 4e reveal the reversible evolution of the cell impedance as a function of the state of charge. Furthermore, Fig. 
S6 and Table S1 of the Supporting Information report the results of NLLS analysis of the impedance spectra in terms of simulated Nyquist plot and interphase resistances, respectively. The impedance response of the cell reflects the contribution of several resistive (R) and pseudocapacitive elements (Q) arranged as shown in the equivalent circuit representation of Table S1. Thus, the several elements account for the electrolyte resistance, the $\mathrm{Na}^{+}$diffusion within the electrode passivation layers, the electrode charge transfer, and possibly the $\mathrm{Na}^{+}$diffusion into the NCAM electrode. The accuracy of the NLLS analysis is well suggested by the good agreement between the experimental and simulated impedance data (Fig. S6), as well as by $\chi^{2}$ values of the order of $10^{-5}-10^{-4}$ (Table S1). The Na/NCAM cell exhibits typical EIS responses at the several states of charge, characterized by relatively low electrode/electrolyte interphase resistance at intermediate voltage, with values ranging from about $50 \Omega$ to about $900 \Omega$, depending on the state of the charge, and high resistances ranging from about $1600 \Omega$ to about $4000 \Omega$ at 1.4 and at 4.6 V, i.e., at high and low sodium content in the layered $\mathrm{Na}_{1-x} \mathrm{Al}_{0.03} \mathrm{Co} 0 .{ }_{18} \mathrm{Ni}_{0.18} \mathrm{Mn}_{0.47} \mathrm{O}_{2}$ material, respectively. Such a behavior can be attributed to insulating character of the almost fully sodiated and desodiated material, and to hindered $\mathrm{Na}^{+}$diffusion into the electrode, ${ }^{35}$ as indeed suggested by the trend of the $\mathrm{Na}^{+}$diffusion coefficients for $\mathrm{Na}_{1-x} \mathrm{Al}_{0.03} \mathrm{Co}_{0.18} \mathrm{Ni}_{0.18} \mathrm{Mn}_{0.47} \mathrm{O}_{2}$ determined both by $\mathrm{CV}$ and by GITT (see discussion of Fig. 3 ). 

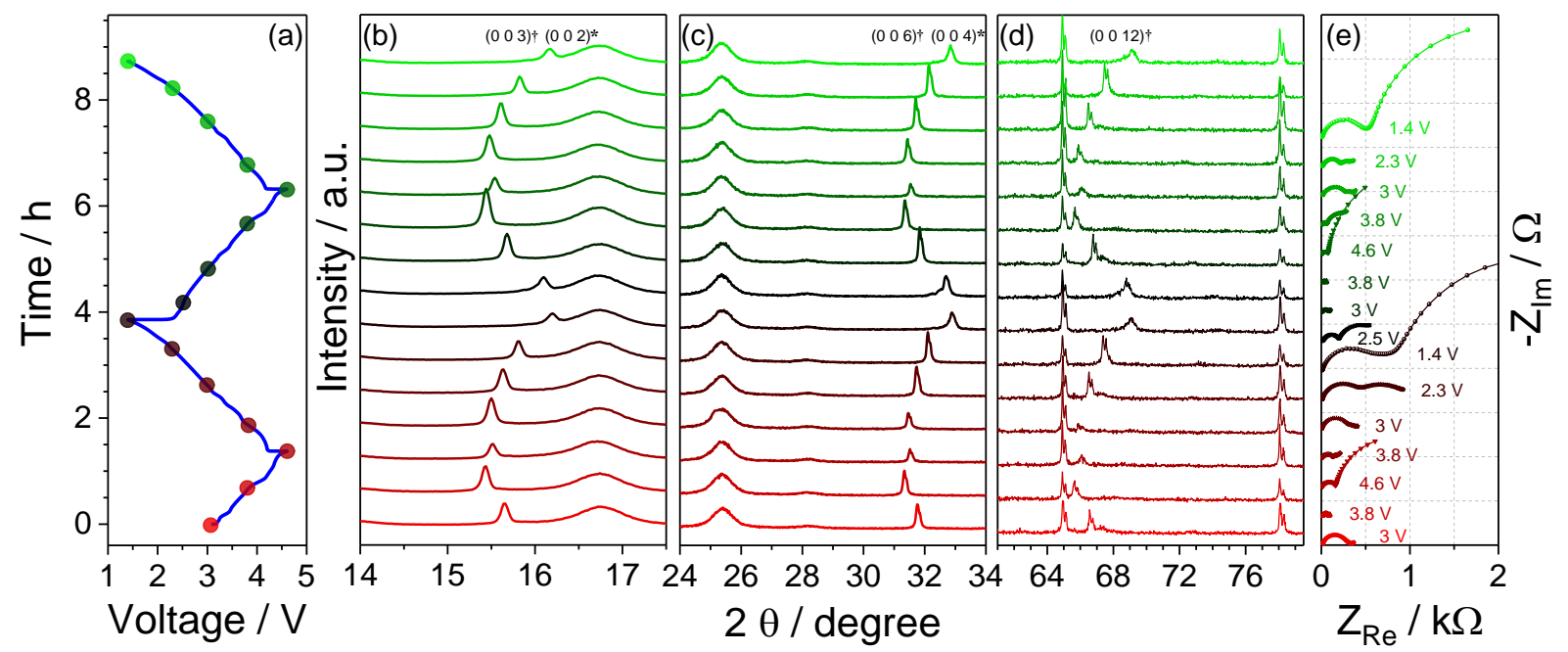

Figure 4. Structural and impedance evolution of the $\mathrm{Na}_{0.48} \mathrm{Al}_{0.03} \mathrm{Co}_{0.18} \mathrm{Ni}_{0.18} \mathrm{Mn}_{0.47} \mathrm{O}_{2}$ electrode throughout galvanostatic cycling as studied by ex situ XRD and EIS (see the Experimental section for further details on the adopted procedure). In detail: (a) voltage profile of the Na/1 M $\mathrm{NaClO}_{4} \mathrm{PC}, 20 \mathrm{wt} \%$ FEC/Na0.48 $\mathrm{Al}_{0.03} \mathrm{Co} 0.18 \mathrm{Ni}_{0.18} \mathrm{Mn}_{0.47} \mathrm{O}_{2}$ cell upon two galvanostatic cycles at $60 \mathrm{~mA} \mathrm{~g}^{-1}$ between 1.4 and $4.6 \mathrm{~V}$, with indication of the voltage values related to the ex situ measurements; (b, c, d) XRD patterns of the $\mathrm{Na}_{0.48} \mathrm{Al}_{0.03} \mathrm{Co}{ }_{0.18} \mathrm{Ni}_{0.18} \mathrm{Mn}_{0.47} \mathrm{O}_{2}$ electrode within $2 \theta$ ranges of (b) $14-17.5^{\circ}$, (c) $24-34^{\circ}$, and (d) $61-79.5^{\circ}$ at the various states of charge as indicated in panel a the symbol $\uparrow$ indicates the reflections of the P3 phase, while the symbol * indicates the reflections of the P2 phase); (e) Nyquist plots of EIS measurements on the Na/1 M $\mathrm{NaClO}_{4} \mathrm{PC}, 20 \mathrm{wt} \% \mathrm{FEC} / \mathrm{Na}_{0.48} \mathrm{Al}_{0.03} \mathrm{Co}_{0.18} \mathrm{Ni}_{0.18} \mathrm{Mn}_{0.47} \mathrm{O}_{2}$ cell within the $500 \mathrm{kHz}-50 \mathrm{~Hz}$ range, at the various states of charge as indicated in panel a (see Fig. S6 and Table S1 in the Supporting Information for the related NLLS analysis). ${ }^{38,39}$

In summary, GITT, $\mathrm{CV}$ and XRD suggest a fast and highly reversible $\mathrm{Na}^{+}$intercalation process within the NCAM electrode above $2.5 \mathrm{~V}$ vs $\mathrm{Na}^{+} / \mathrm{Na}$, favored by the absence of phase transition within the stable $\mathrm{Na}_{1-x} \mathrm{Al}_{0.03} \mathrm{Co}_{0.18} \mathrm{Ni}_{0.18} \mathrm{Mn}_{0.47} \mathrm{O}_{2}$ layered structure. ${ }^{26}$ Therefore, galvanostatic cycling test of NCAM at increasing current has been performed herein to evaluate the rate capability of the material and reported in Fig. 5a-b. The Na/NCAM cell exhibits the 
expected voltage signature characterized by rather linear curves according to GITT, and limited polarization which increases at high current (Fig. 5a). The cell delivers reversible capacity of about 170, 154, 139, 122, and $106 \mathrm{mAh} \mathrm{g}^{-1}$ at current of 15, 30, 60, 120, and $240 \mathrm{~mA} \mathrm{~g}^{-1}$, respectively, recovering a capacity of about $160 \mathrm{mAh} \mathrm{g}^{-1}$ as the current is decreased to $15 \mathrm{~mA}$ $\mathrm{g}^{-1}$ at the $26^{\text {th }}$ cycle (Fig. 5b). Furthermore, the cycling stability of the material has been evaluated by galvanostatic tests over 50 cycles at constant rates of 15, 60, and $120 \mathrm{~mA} \mathrm{~g}^{-1}$ (Fig. $5 \mathrm{c}-\mathrm{f})$. The cycling tests reveal at the various currents an average working voltage of about $3 \mathrm{~V}$ (Fig. 5c-e) with stable sloped profile ascribed to a solid-solution reaction into multi-metal structure of the NCAM material, without significant P3 or P2 phase transition upon $\mathrm{Na}^{+}$ intercalation within the $\mathrm{MeO}_{6}$ layers. ${ }^{34-36}$ It is noteworthy that such a characteristic profile may be particularly suitable for a proper voltage cutoffs tuning and electrode balancing in full-cell array using a sodium-ion anode. ${ }^{12,52-54}$ However, the low charge capacity at the first cycle, i.e., about $100 \mathrm{mAh} \mathrm{g}^{-1}$ (see insets of panels c-e), may require sacrificial agents, pre-sodiation procedures, or proper full-cell balance to compensate the sodium deficiency of the starting composition ( $\left.\mathrm{Na}_{0.48} \mathrm{Al}_{0.03} \mathrm{Co}_{0.18} \mathrm{Ni}_{0.18} \mathrm{Mn}_{0.47} \mathrm{O}_{2}\right){ }^{5}$ The $\mathrm{Na} / \mathrm{NCAM}$ cell exhibits a relatively stable cycling trend, with initial capacity of 160 and $148 \mathrm{mAh} \mathrm{g}^{-1}$ at 60 and $120 \mathrm{~mA} \mathrm{~g}^{-1}$, respectively, decreasing to the $81 \%$ after 50 cycles (Fig. $5 \mathrm{f}$ ). Cycling at lower rate of $15 \mathrm{~mA} \mathrm{~g}^{-1}$ leads to higher initial capacity, i.e., $176 \mathrm{mAh} \mathrm{g}^{-1}$, but faster fading to $70 \%$ after 50 cycles, which may be reasonably attributed to possible electrolyte decomposition at the higher voltage values. ${ }^{35}$ The fading trend is in agreement with the average Columbic efficiency after the $5^{\text {th }}$ cycle, which decreases from $99 \%$ at 60 and $120 \mathrm{~mA} \mathrm{~g}^{-1}$ to $98 \%$ at $15 \mathrm{~mA} \mathrm{~g}^{-1}$. Accordingly, a further improvement in terms of cycling stability may be achieved by using optimized electrolyte formulations ${ }^{55}$ and by finely tuning the working voltage window. 

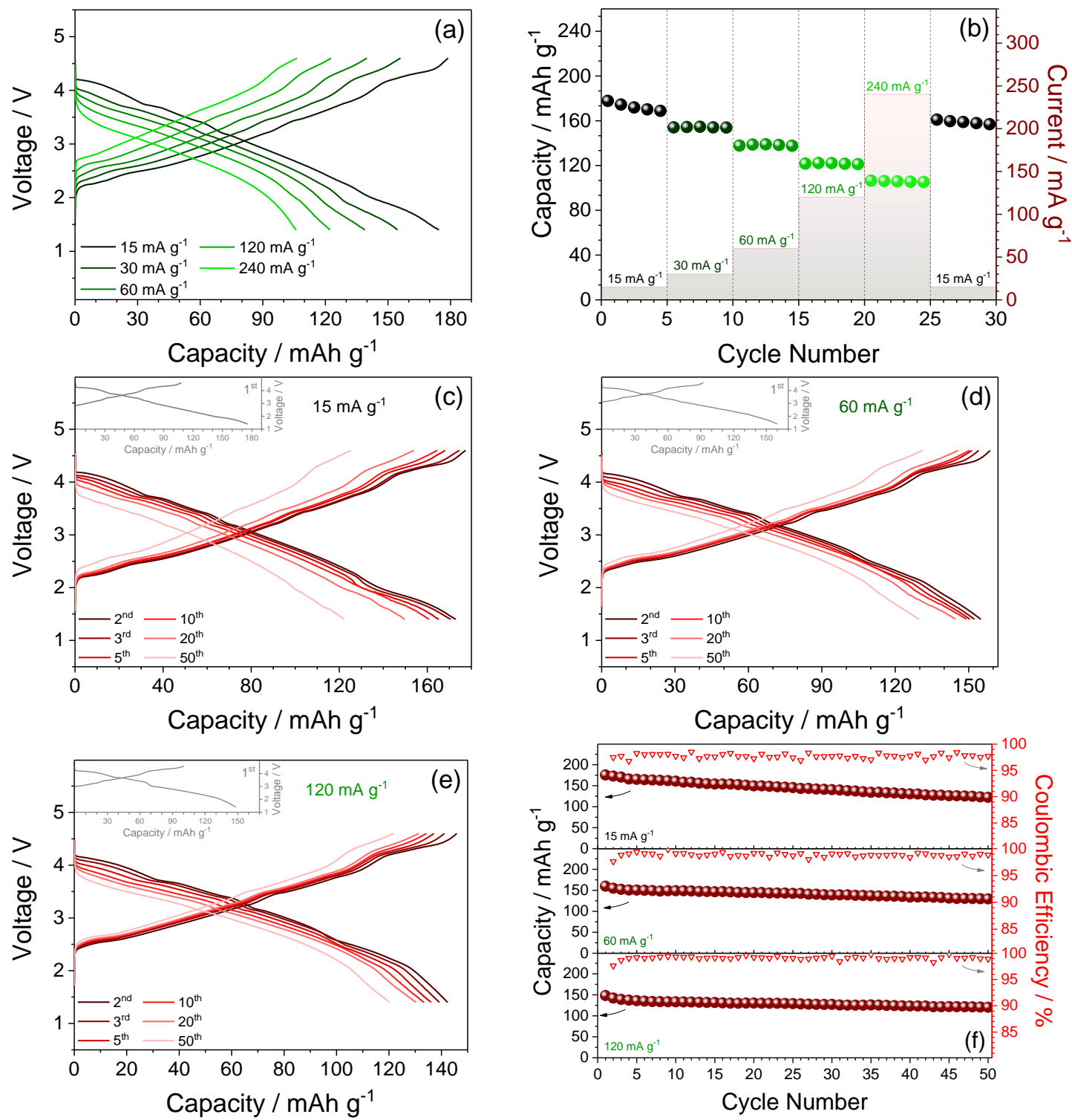

Figure 5. Cycling performance of the $\mathrm{Na} 0.48 \mathrm{Al}_{0.03} \mathrm{Co}_{0.18} \mathrm{Ni}_{0.18} \mathrm{Mn}_{0.47} \mathrm{O}_{2}$ cathode in sodium cell using $1 \mathrm{M} \mathrm{NaClO}_{4} \mathrm{PC}, 20 \mathrm{wt} \%$ FEC as electrolyte within the $1.4-4.6 \mathrm{~V}$ range. (a, b) Rate capability test at currents of $15,30,60,120$, and $240 \mathrm{~mA} \mathrm{~g}^{-1}$ in terms of (a) voltage profiles and (b) cycling behavior (discharge capacity and applied current on the left and right y-axes, respectively). (c-f) Galvanostatic tests at currents of (c) 15, (d) 60, and (e) $120 \mathrm{~mA} \mathrm{~g}^{-1}$ in terms of (c-e) voltage profiles of the $2^{\text {nd }}, 3^{\text {rd }}, 5^{\text {th }}, 10^{\text {th }}, 20^{\text {th }}$, and $50^{\text {th }}$ cycle $\left(1^{\text {st }}\right.$ cycle in inset) and (f) cycling behavior (discharge capacity and Coulombic efficiency on the left and right y-axes, respectively). 


\section{Conclusion}

A novel $\mathrm{Na} 0.48 \mathrm{Al}_{0.03} \mathrm{Co}{ }_{0.18} \mathrm{Ni}_{0.18} \mathrm{Mn}_{0.47} \mathrm{O}_{2}$ (NCAM) material was synthesized by a simple coprecipitation method and studied as positive electrode for sodium-ion batteries. The NCAM cathode revealed mixed P3/P2-type structure (79:21 vol.\%, respectively) and a morphology consisting of primary layers with nanometric thickness regularly stacked into uniform micrometric particles. Remarkably ordered morphology and tailored structure allowed fast $\mathrm{Na}^{+}$ transport within the NCAM electrode, beside the expected diffusion coefficient decrease and charge transfer increase in the full charge and discharge conditions, as revealed by GITT, CV and EIS. The layered framework was able to reversibly intercalate $\mathrm{Na}^{+}$ions through a solidsolution mechanism between the composition range from $\mathrm{Na}_{0.80} \mathrm{Al}_{0.03} \mathrm{Co}{ }_{0.18} \mathrm{Ni}_{0.18} \mathrm{Mn}_{0.47} \mathrm{O}_{2}$ to $\mathrm{Na}_{0.17} \mathrm{Al}_{0.03} \mathrm{Co}_{0.18} \mathrm{Ni}_{0.18} \mathrm{Mn}_{0.47} \mathrm{O}_{2}$, without showing any phase change as evidenced by $\mathrm{XRD}$ upon electrode operation in sodium cell. Therefore, P3 and P2 phases were retained by cycling despite the unit expansion and shrinking promoted by extraction and reverse insertion of the sodium ions. Such a structural stability upon sodium (de)intercalation was reflected into a smooth potential profile between 1.4 and $4.6 \mathrm{~V} v s \mathrm{Na}^{+} / \mathrm{Na}$, high rate performance with capacity ranging between 170 and $106 \mathrm{mAh} \mathrm{g}^{-1}$ by raising the current from 15 to $240 \mathrm{~mA} \mathrm{~g}^{-1}$, as well as suitable cycling stability and Coulombic of about $99 \%$ upon 50 cycles. Therefore, the remarkable stability of the NCAM structure upon fast sodium (de)intercalation, and the limited phase change upon cycling due to the inclusion of $\mathrm{Al}, \mathrm{Co}, \mathrm{Ni}$, and $\mathrm{Mn}$ in the layered oxide composition indicated the beneficial effect of the concomitant presence of various metals, thus suggesting the multi-metal approach as a viable strategy for achieving high performances sodium ion battery cathodes. 
Supporting Information. XRD pattern with reference bars of the P3-type (ICSD 184736) and P2-type (ICSD 291156) structures and SEM-EDS analysis for $\mathrm{Na}_{0.48} \mathrm{Al}_{0.03} \mathrm{Co} 0.18 \mathrm{Ni} 0.18 \mathrm{Mn} 0.47 \mathrm{O}_{2}$ (NCAM) powder (Fig. S1, Fig. S2, respectively). Analysis of CV measurements on the NCAM cathode in sodium cell to calculate the sodium-diffusion coefficient $\left(D_{\mathrm{Cv}}\right)$ according to the Randles-Sevcik equation (Fig. S3). Galvanostatic voltage profiles as a function of $\mathrm{Na}^{+}$exchange degree $\left(x\right.$ in $\mathrm{Na}_{1-x} \mathrm{Al}_{0.03} \mathrm{Co}_{0.18} \mathrm{Ni}_{0.18} \mathrm{Mn}_{0.47} \mathrm{O}_{2}$ ) for the NCAM cathode in sodium cell (Fig. S4). GITT analysis for the NCAM cathode in sodium cell performed to evaluate the $\mathrm{Na}^{+}$diffusion coefficient (Fig. S5). NLLS analysis of EIS measurements at several states of charge performed on the NCAM cathode in sodium cell (Fig. S6).

\section{Acknowledgements}

The work was founded by the grant "Fondo di Ateneo per la Ricerca Locale (FAR) 2017", University of Ferrara, and performed within the collaboration project "Accordo di Collaborazione Quadro 2015" between the University of Ferrara (Department of Chemical and Pharmaceutical Sciences) and the Sapienza University of Rome (Department of Chemistry).

\section{References}

(1) Kundu, D.; Talaie, E.; Duffort, V.; Nazar, L. F. The Emerging Chemistry of Sodium Ion Batteries for Electrochemical Energy Storage. Angew. Chemie - Int. Ed. 2015, 54, 34323448.

(2) Scrosati, B. Lithium Rocking Chair Batteries: An Old Concept? J. Electrochem. Soc. 1992, 139, 2776-2781.

(3) Di Lecce, D.; Verrelli, R.; Hassoun, J. Lithium-Ion Batteries for Sustainable Energy Storage: Recent Advances towards New Cell Configurations. Green Chem. 2017, 19, 
3442-3467.

(4) Narins, T. P. The Battery Business: Lithium Availability and the Growth of the Global Electric Car Industry. Extr. Ind. Soc. 2017, 4, 321-328.

(5) Hwang, J.-Y.; Myung, S.-T.; Sun, Y.-K. Sodium-Ion Batteries: Present and Future. Chem. Soc. Rev. 2017, 46, 3529-3614.

(6) Yabuuchi, N.; Kubota, K.; Dahbi, M.; Komaba, S. Research Development on Sodium-Ion Batteries. Chem. Rev. 2014, 114, 11636-11682.

(7) Hasa, I.; Hassoun, J.; Passerini, S. Nanostructured Na-Ion and Li-Ion Anodes for Battery Application: A Comparative Overview. Nano Res. 2017, 10, 3942-3969.

(8) Palomares, V.; Serras, P.; Villaluenga, I.; Hueso, K. B.; Carretero-González, J.; Rojo, T. Na-Ion Batteries, Recent Advances and Present Challenges to Become Low Cost Energy Storage Systems. Energy Environ. Sci. 2012, 5, 5884-5901.

(9) Han, M. H.; Gonzalo, E.; Singh, G.; Rojo, T. A Comprehensive Review of Sodium Layered Oxides: Powerful Cathodes for Na-Ion Batteries. Energy Environ. Sci. 2015, 8, 81-102.

(10) Hwang, J.-Y.; Yoon, C. S.; Belharouak, I.; Sun, Y.-K. A Comprehensive Study of the Role of Transition Metals in O3-Type Layered $\mathrm{Na}\left[\mathrm{Ni}_{\mathrm{x}} \mathrm{Co}_{\mathrm{y}} \mathrm{Mn}_{\mathrm{z}}\right] \mathrm{O}_{2}(\mathrm{x}=1 / 3,0.5,0.6$, and 0.8) Cathodes for Sodium-Ion Batteries. J. Mater. Chem. A 2016, 4, 17952-17959.

(11) Hasa, I.; Buchholz, D.; Passerini, S.; Scrosati, B.; Hassoun, J. High Performance $\mathrm{Na} 0.5\left[\mathrm{Ni} 0.23 \mathrm{Fe} 0.13 \mathrm{Mn}_{0.63}\right] \mathrm{O}_{2}$ Cathode for Sodium-Ion Batteries. Adv. Energy Mater. 2014, 4, 1400083.

(12) Hasa, I.; Dou, X.; Buchholz, D.; Shao-Horn, Y.; Hassoun, J.; Passerini, S.; Scrosati, B. A Sodium-Ion Battery Exploiting Layered Oxide Cathode, Graphite Anode and Glyme- 
Based Electrolyte. J. Power Sources 2016, 310, 26-31.

(13) Fang, Y.; Zhang, J.; Xiao, L.; Ai, X.; Cao, Y.; Yang, H. Phosphate Framework Electrode Materials for Sodium Ion Batteries. Adv. Sci. 2017, 4, 1600392.

(14) Hasa, I.; Hassoun, J.; Sun, Y. K.; Scrosati, B. Sodium-Ion Battery Based on an Electrochemically Converted $\mathrm{NaFePO}_{4}$ Cathode and Nanostructured Tin-Carbon Anode. ChemPhysChem 2014, 15, 2152-2155.

(15) Ming, J.; Ming, H.; Yang, W.; Kwak, W.-J.; Park, J.-B.; Zheng, J.; Sun, Y.-K. A Sustainable Iron-Based Sodium Ion Battery of Porous Carbon- $\mathrm{Fe}_{3} \mathrm{O}_{4} / \mathrm{Na}_{2} \mathrm{FeP}_{2} \mathrm{O}_{7}$ with High Performance. RSC Adv. 2015, 5, 8793-8800.

(16) Jung, Y. H.; Lim, C. H.; Kim, D. K. Graphene-Supported $\mathrm{Na}_{3} \mathrm{~V}_{2}\left(\mathrm{PO}_{4}\right)_{3}$ as a High Rate Cathode Material for Sodium-Ion Batteries. J. Mater. Chem. A 2013, 1, 11350-11354.

(17) Chung, S. C.; Ming, J.; Lander, L.; Lu, J.; Yamada, A. Rhombohedral NASICON-Type $\mathrm{Na}_{x} \mathrm{Fe}_{2}\left(\mathrm{SO}_{4}\right)_{3}$ for Sodium Ion Batteries: Comparison with Phosphate and Alluaudite Phases. J. Mater. Chem. A 2018, 6, 3919-3925.

(18) Lu, Y.; Wang, L.; Cheng, J.; Goodenough, J. B. Prussian Blue: A New Framework of Electrode Materials for Sodium Batteries. Chem. Commun. 2012, 48, 6544-6546.

(19) Song, J.; Wang, L.; Lu, Y.; Liu, J.; Guo, B.; Xiao, P.; Lee, J.-J.; Yang, X.-Q.; Henkelman, G.; Goodenough, J. B. Removal of Interstitial $\mathrm{H}_{2} \mathrm{O}$ in Hexacyanometallates for a Superior Cathode of a Sodium-Ion Battery. J. Am. Chem. Soc. 2015, 137, 2658-2664.

(20) Wang, L.; Lu, Y.; Liu, J.; Xu, M.; Cheng, J.; Zhang, D.; Goodenough, J. B. A Superior Low-Cost Cathode for a Na-Ion Battery. Angew. Chemie - Int. Ed. 2013, 52, 1964-1967.

(21) Delmas, C.; Fouassier, C.; Hagenmuller, P. Structural Classification and Properties of the Layered Oxides. Phys. $B+C$ 1980, 99, 81-85. 
(22) Singh, G.; López Del Amo, J. M.; Galceran, M.; Pérez-Villar, S.; Rojo, T. Structural Evolution during Sodium Deintercalation/Intercalation in $\mathrm{Na}_{2 / 3}\left[\mathrm{Fe}_{1 / 2} \mathrm{Mn}_{1 / 2}\right] \mathrm{O}_{2}$. J. Mater. Chem. A 2015, 3, 6954-6961.

(23) Vinckevičiûte, J.; Radin, M. D.; Van Der Ven, A. Stacking-Sequence Changes and Na Ordering in Layered Intercalation Materials. Chem. Mater. 2016, 28, 8640-8650.

(24) Jo, J. H.; Choi, J. U.; Konarov, A.; Yashiro, H.; Yuan, S.; Shi, L.; Sun, Y. K.; Myung, S. T. Sodium-Ion Batteries: Building Effective Layered Cathode Materials with Long-Term Cycling by Modifying the Surface via Sodium Phosphate. Adv. Funct. Mater. 2018, 28, 111.

(25) Komaba, S.; Yabuuchi, N.; Nakayama, T.; Ogata, A.; Ishikawa, T.; Nakai, I. Study on the Reversible Electrode Reaction of $\mathrm{Na}_{1-x} \mathrm{Ni}_{0.5} \mathrm{Mn}_{0.5} \mathrm{O}_{2}$ for a Rechargeable Sodium-Ion Battery. Inorg. Chem. 2012, 51, 6211-6220.

(26) Ortiz-Vitoriano, N.; Drewett, N. E.; Gonzalo, E.; Rojo, T. High Performance ManganeseBased Layered Oxide Cathodes: Overcoming the Challenges of Sodium Ion Batteries. Energy Environ. Sci. 2017, 10, 1051-1074.

(27) Talaie, E.; Duffort, V.; Smith, H. L.; Fultz, B.; Nazar, L. F. Structure of the High Voltage Phase of Layered P2-Na2/3-z $\left[\mathrm{Mn}_{1 / 2} \mathrm{Fe}_{1 / 2}\right] \mathrm{O}_{2}$ and the Positive Effect of Ni Substitution on Its Stability. Energy Environ. Sci. 2015, 8, 2512-2523.

(28) Guo, S.; Sun, Y.; Yi, J.; Zhu, K.; Liu, P.; Zhu, Y.; Zhu, G.; Chen, M.; Ishida, M.; Zhou, H. Understanding Sodium-Ion Diffusion in Layered P2 and P3 Oxides via Experiments and First-Principles Calculations: A Bridge between Crystal Structure and Electrochemical Performance. NPG Asia Mater. 2016, 8, e266.

(29) Hwang, J. Y.; Myung, S. T.; Choi, J. U.; Yoon, C. S.; Yashiro, H.; Sun, Y. K. Resolving 
the Degradation Pathways of the O3-Type Layered Oxide Cathode Surface through the Nano-Scale Aluminum Oxide Coating for High-Energy Density Sodium-Ion Batteries. J. Mater. Chem. A 2017, 5, 23671-23680.

Li, Z.-Y.; Wang, H.; Yang, W.; Yang, J.; Zheng, L.; Chen, D.; Sun, K.; Han, S.; Liu, X. Modulating the Electrochemical Performances of Layered Cathode Materials for Sodium Ion Batteries through Tuning Coulombic Repulsion between Negatively Charged $\mathrm{TMO}_{2}$ Slabs. ACS Appl. Mater. Interfaces 2018, 10, 1707-1718.

Oh, S.-M.; Myung, S.-T.; Yoon, C. S.; Lu, J.; Hassoun, J.; Scrosati, B.; Amine, K.; Sun, Y.-K. Advanced $\mathrm{Na}\left[\mathrm{Ni} 0.25 \mathrm{Fe}_{0.5} \mathrm{Mn}_{0.25} \mathrm{O}_{2} / \mathrm{C}-\mathrm{Fe}_{3} \mathrm{O}_{4}\right.$ Sodium-Ion Batteries Using EMS Electrolyte for Energy Storage. Nano Lett. 2014, 14, 1620-1626.

Xu, G.-L.; Amine, R.; Xu, Y.-F.; Liu, J.; Gim, J.; Ma, T.; Ren, Y.; Sun, C.-J.; Liu, Y.; Zhang, X.; Heald, S.M.; Solhy, A.; Saadoune, I.; Mattis, W.L.; Sun, S.-G.; Chen, Z.; Amine, K. Insights into the Structural Effects of Layered Cathode Materials for High Voltage Sodium-Ion Batteries. Energy Environ. Sci. 2017, 10, 1677-1693.

(33) Bucher, N.; Hartung, S.; Franklin, J. B.; Wise, A. M.; Lim, L. Y.; Chen, H. Y.; Weker, J. N.; Toney, M. F.; Srinivasan, M. P2-Nax $\mathrm{Co}_{y} \mathrm{Mn}_{1-y} \mathrm{O}_{2}(y=0,0.1)$ as Cathode Materials in Sodium-Ion Batteries - Effects of Doping and Morphology to Enhance Cycling Stability. Chem. Mater. 2016, 28, 2041-2051.

(34) Hasa, I.; Buchholz, D.; Passerini, S.; Hassoun, J. A Comparative Study of Layered Transition Metal Oxide Cathodes for Application in Sodium-Ion Battery. ACS Appl. Mater. Interfaces 2015, 7, 5206-5212.

Hasa, I.; Passerini, S.; Hassoun, J. Toward High Energy Density Cathode Materials for Sodium-Ion Batteries: Investigating the Beneficial Effect of Aluminum Doping on the P2- 
Type Structure. J. Mater. Chem. A 2017, 5, 4467-4477.

(36) Singh, G.; Tapia-Ruiz, N.; Lopez Del Amo, J. M.; Maitra, U.; Somerville, J. W.; Armstrong, A. R.; Martinez De Ilarduya, J.; Rojo, T.; Bruce, P. G. High Voltage MgDoped Na0.67Ni0.3-x $\mathrm{Mg}_{x} \mathrm{Mn}_{0.7} \mathrm{O}_{2}(\mathrm{x}=0.05,0.1)$ Na-Ion Cathodes with Enhanced Stability and Rate Capability. Chem. Mater. 2016, 28, 5087-5094.

(37) Lutterotti, L. Total Pattern Fitting for the Combined Size-strain-stress-texture Determination in Thin Film Diffraction. Nucl. Instruments Methods Phys. Res. Sect. B Beam Interact. with Mater. Atoms 2010, 268, 334-340.

(38) Boukamp, B. A. A Nonlinear Least Squares Fit Procedure for Analysis of Immittance Data of Electrochemical Systems. Solid State Ionics 1986, 20, 31-44.

(39) Boukamp, B. A Package for Impedance/Admittance Data Analysis. Solid State Ionics 1986, 18-19, 136-140.

(40) Wang, P. F.; Yao, H. R.; Liu, X. Y.; Zhang, J. N.; Gu, L.; Yu, X. Q.; Yin, Y. X.; Guo, Y. G. Ti-Substituted NaNio.5Mn0.5-XTix $\mathrm{O}_{2}$ Cathodes with Reversible O3-P3 Phase Transition for High-Performance Sodium-Ion Batteries. Adv. Mater. 2017, 29, 1-7.

(41) Dai, K.; Mao, J.; Song, X.; Battaglia, V.; Liu, G. Na0.44MnO2 with Very Fast Sodium Diffusion and Stable Cycling Synthesized via Polyvinylpyrrolidone-Combustion Method. J. Power Sources 2015, 285, 161-168.

(42) Hwang, J. Y.; Myung, S. T.; Yoon, C. S.; Kim, S. S.; Aurbach, D.; Sun, Y. K. Novel Cathode Materials for Na-Ion Batteries Composed of Spoke-Like Nanorods of $\mathrm{Na}\left[\mathrm{Ni}_{0.61} \mathrm{Co}_{0.12} \mathrm{Mn}_{0.27}\right] \mathrm{O}_{2}$ Assembled in Spherical Secondary Particles. Adv. Funct. Mater. 2016, 26, 8083-8093.

(43) Bruce, P. G.; Scrosati, B.; Tarascon, J.-M. Nanomaterials for Rechargeable Lithium 
Batteries. Angew. Chemie Int. Ed. 2008, 47, 2930-2946.

(44) Yuan, D.; He, W.; Pei, F.; Wu, F.; Wu, Y.; Qian, J.; Cao, Y.; Ai, X.; Yang, H. Synthesis and Electrochemical Behaviors of Layered Na0.67 $[\mathrm{Mn} 0.65 \mathrm{Co} 0.2 \mathrm{Ni} 0.15] \mathrm{O}_{2}$ Microflakes as a Stable Cathode Material for Sodium-Ion Batteries. J. Mater. Chem. A 2013, 1, 3895-3899.

(45) Oh, S. M.; Myung, S. T.; Jang, M. W.; Scrosati, B.; Hassoun, J.; Sun, Y. K. An Advanced Sodium-Ion Rechargeable Battery Based on a Tin-Carbon Anode and a Layered Oxide Framework Cathode. Phys. Chem. Chem. Phys. 2013, 15, 3827-3833.

Wang, P.-F.; You, Y.; Yin, Y.-X.; Guo, Y.-G. An O3-Type NaNio.5Mn0.5O2 Cathode for Sodium-Ion Batteries with Improved Rate Performance and Cycling Stability. J. Mater. Chem. A 2016, 4, 17660-17664.

(47) Di Lecce, D.; Hassoun, J. Lithium Transport Properties in $\mathrm{LiMn}_{1-\alpha} \mathrm{Fe}_{\alpha} \mathrm{PO}_{4}$ Olivine Cathodes. J. Phys. Chem. C 2015, 119, 20855-20863.

(48) Weppner, W.; Hugguns, R. A. Determination of the Kinetic Parameters of MixedConducting Electrodes and Application to the System Li33b. J. Electrochem. Soc. 1977, $124,1569-1578$.

(49) Di Lecce, D.; Brescia, R.; Scarpellini, A.; Prato, M.; Hassoun, J. A High Voltage Olivine Cathode for Application in Lithium-Ion Batteries. ChemSusChem 2016, 9, 223-230.

(50) Mortemard De Boisse, B.; Carlier, D.; Guignard, M.; Bourgeois, L.; Delmas, C. P2$\mathrm{Na}_{x} \mathrm{Mn}_{1 / 2} \mathrm{Fe}_{1 / 2} \mathrm{O}_{2}$ Phase Used as Positive Electrode in Na Batteries: Structural Changes Induced by the Electrochemical (De)Intercalation Process. Inorg. Chem. 2014, 53, 1119711205.

(51) Chen, X.; Zhou, X.; Hu, M.; Liang, J.; Wu, D.; Wei, J.; Zhou, Z. Stable Layered P3/P2 Na0.66 Co $0.5 \mathrm{Mn}_{0.5} \mathrm{O}_{2}$ cathode Materials for Sodium-Ion Batteries. J. Mater. Chem. A 2015, 
3, 20708-20714.

(52) Di Lecce, D.; Andreotti, P.; Boni, M.; Gasparro, G.; Rizzati, G.; Hwang, J.-Y.; Sun, Y.K.; Hassoun, J. Multiwalled Carbon Nanotubes Anode in Lithium-Ion Battery with $\mathrm{LiCoO}_{2}, \mathrm{Li}\left[\mathrm{Ni}_{1 / 3} \mathrm{Co}_{1 / 3} \mathrm{Mn}_{1 / 3}\right] \mathrm{O}_{2}$, and $\mathrm{LiFe}_{1 / 4} \mathrm{Mn}_{1 / 2} \mathrm{Co}_{1 / 4} \mathrm{PO}_{4}$ Cathodes. ACS Sustain. Chem. Eng. 2018, 6, 3225-3232.

(53) Hasa, I.; Passerini, S.; Hassoun, J. A Rechargeable Sodium-Ion Battery Using a Nanostructured $\mathrm{Sb}-\mathrm{C}$ Anode and P2-Type Layered $\mathrm{Na}_{0.6} \mathrm{Ni}_{0.22} \mathrm{Fe}_{0.11} \mathrm{Mn}_{0.66} \mathrm{O}_{2}$ Cathode. RSC Adv. 2015, 5, 48928-48934.

(54) Hasa, I.; Passerini, S.; Hassoun, J. Characteristics of an Ionic Liquid Electrolyte for Sodium-Ion Batteries. J. Power Sources 2016, 303, 203-207.

(55) Komaba, S.; Ishikawa, T.; Yabuuchi, N.; Murata, W.; Ito, A.; Ohsawa, Y. Fluorinated Ethylene Carbonate as Electrolyte Additive for Rechargeable Na Batteries. ACS Appl. Mater. Interfaces 2011, 3, 4165-4168. 
TOC Graphic

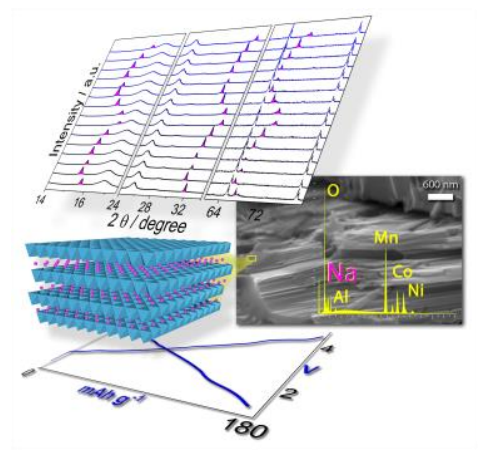

